\title{
Non-surgical acute traumatic perianal injuries
}

\author{
Mehmet Aykut Yıldırım ${ }^{1}$, Murat Çakır ${ }^{1}$ \\ ${ }^{1}$ Deparment of General Surgery, Necmettin Erbakan University Meram School of Medicine, Konya, Turkey
}

\begin{abstract}
Objective: The diagnosis of fecal incontinence is challenging and complex. One of the most significant causes of fecal incontinence is trauma in the perianal area. The most important cause of such trauma is birth trauma. It is hard to evaluate patients and plan treatment. Surgical method is determined by the severity of sphincter damage and injuries formed in the organs in the perianal area. The aim of this study, therefore, was to analyze the cases of patients who had undergone sphincter repair because of acute injuries in the perianal area.
\end{abstract}

Material and Methods: The cases of 15 patients with perianal area injuries who had presented to Necmettin Erbakan University Meram Medical School's General Surgery Clinic between 2010 and 2015 were retrospectively analyzed. Data on age, sex, form of injury, severity of injury, time of first response, form of repair, injury problems, and post-operative complications of the patients were investigated. The patients' long-term results were analyzed.

Results: While 5 of the patients were male, 10 were female. 9 of the female patients had birth trauma, while one had injury during sexual intercourse. While all of the patients received sphincteroplasty, 10 had levatoroplasty. All the female patients received vaginoplasty.

Conclusion: We are of the opinion that it is significant to have surgical intervention before tissue edema develops.

Keywords: Fecal incontinence, trauma, perianal

Cite this article as: Yıldırım MA, Çakır M. Non-surgical acute traumatic perianal injuries. Turk J Surg 2019; 35 (1): $44-48$

Corresponding Author Mehmet Aykut Yıldırım

E-mail: drmayildirim@hotmail.com

Received: 20.04 .2018

Accepted: 28.06 .2018

Available Online Date: 01.03.2019

o Copyright 2019 by Turkish Surgical Society Available online at www.turkjsurg.com

DOI: $10.5578 /$ turkjsurg.4188

\section{INTRODUCTION}

Fecal incontinence is a condition that has social and economic effects and disrupts quality of life (1). It is hard to offer an exact definition of fecal incontinence. It can, however, be defined as the failure to control the anal discharge of intestinal content at an appropriate time and place (2). The prevalence, diagnosis, and treatment methods of fecal incontinence have not been clearly ascertained. Many methods used in diagnosis and treatment have been transformed in time (3). The diagnosis of fecal incontinence is challenging and complex. One of the most significant causes of fecal incontinence is trauma in the perianal area. The most important cause of such trauma is birth trauma. It is hard to evaluate patients and plan treatment. Surgical method is determined by the severity of sphincter damage and injuries formed in the organs in the perianal area. The aim of this study, therefore, was to analyze the cases of patients who had undergone sphincter repair because of acute injuries in the perianal area.

\section{MATERIAL and METHODS}

The cases of 15 patients with perianal area injuries who had presented to Necmettin Erbakan University Meram Medical School's General Surgery Clinic between 2010 and 2015 were retrospectively analyzed. Ethics committee approval was received for this study from the ethics committee of Necmettin Erbakan University Meram School of Medicine (10.08.2017-2017/361). Data on age, sex, form of injury, severity of injury, time of first response, form of repair, injury problems, and post-operative complications of the patients were investigated. The patients'long-term results were analyzed. Patients who had not received emergency surgery but undergone repair in the late period and those who had had intraabdominal organ injuries were excluded from the study in line with the exclusion criteria.

\section{RESULTS}

While 5 of the patients were male, 10 were female. 9 of the female patients had birth trauma, while one had injury during sexual intercourse. Mean age of the male 
patients was 36 (25-45) and all had injuries because of falling down from height. The injury extended to the right inguinal area in one of the cases. Mean age of the female patients was 24 (1936) (Table 1). Three of the female patients had type 4, 2 had type $3 a, 2$ had type $3 b$, and 3 had type $3 c$ injuries (Figure 1). Six of the female patients had their first labor. 5 of the cases had childbirth with more than $4000 \mathrm{~g}$. While six of the patients had episiotomy, 3 did not receive episiotomy. Moreover, six of the patients had vacuum assisted extraction during labor.

Male patients were taken into surgery at an average of 8 hours (3-15 hours) after the incident. Nine of the female patients received intervention within the first 10 (1-18) hours. One patient was treated at an external center initially and presented to our center on the $3^{\text {rd }}$ day upon the formation of split in the injury. This patient was re-operated.

While all the patients received sphincteroplasty, 10 had levatoroplasty. All of the female patients received vaginoplasty. Postrepair rectovaginal septum was thicker than $2 \mathrm{~cm}$ in all female patients. 3/0 Polyglactin sutures were used in all repairs and interrupted repair was completed (Figure 2). All patients had

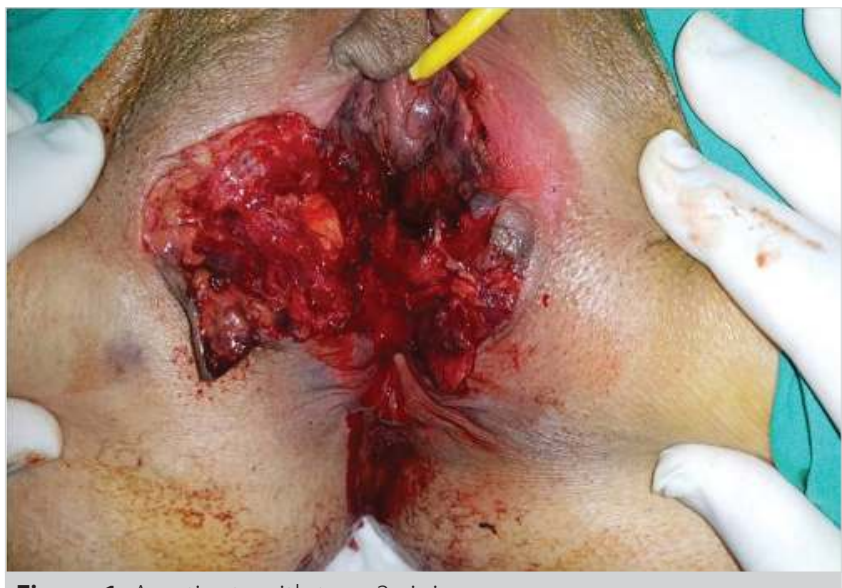

Figure 1. A patients with type 3 c injury.

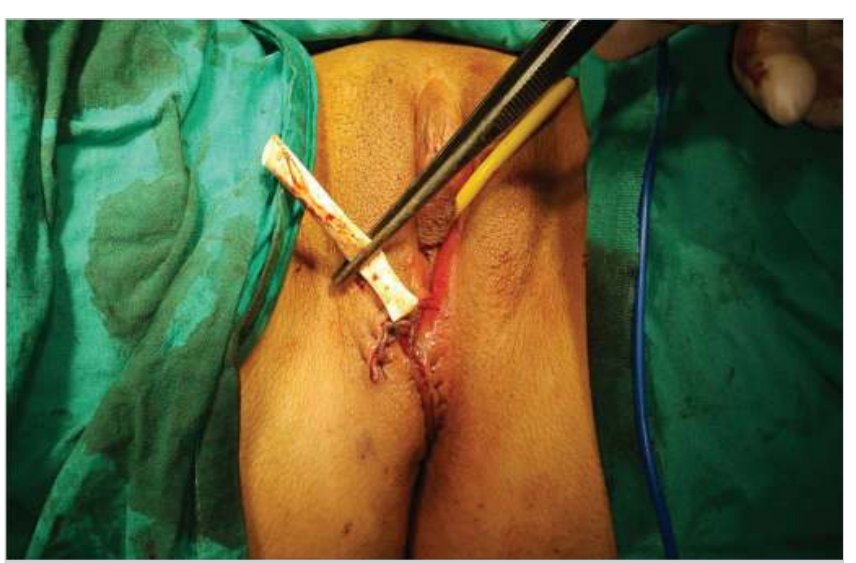

Figure 2. Post-repair image. drains placed. Female patients had vaginal tampons which were frequently changed. All patients had colorectal irrigation during the surgical procedure.

Colostomy was not created for any of the patients, while medical ileus was created. Parenteral feeding was continued for six days. The patients were started on third generation cephalosporin and metronidazole. Oral intake was enabled on the fifth day and the patients were discharged between the $7^{\text {th }}$ and $10^{\text {th }}$ days. Female patients were asked to avoid sexual intercourse for 3 months. They were recommended not to have vaginal childbirth in their following labors. All patients were started on laxatives in order to ease stool discharge and to prevent constipation for a month. This period was prolonged for those patients with chronic constipation.

All patients were followed-up in the $1^{\text {st }}$ consecutive month. None of the patients had wound site pathologies. Anal manometric pressure measurements were done in the $3^{\text {rd }}$ month. Mean resting pressure for male patients was 45 (30-70) $\mathrm{mmHg}$, extrusion pressure was 66 (50-120) $\mathrm{mmHg}$, mean duration of extrusion was 30 (20-56) seconds, and coughing reflex was 74 (54-130) $\mathrm{mmHg}$. Mean resting pressure for female patients was 40 (30-60) mmHg, extrusion pressure was 60 (50-100) mmHg, mean duration of extrusion was 26 (20-50) seconds, and coughing reflex was 68 (54-110) $\mathrm{mmHg}$ (Table 1).

Four patients contracted gas incontinence in the $6^{\text {th }}$ month. These patients received biofeedback for 2 months upon failure to detect complete sphincter damage by imaging techniques. Patients' complaints got better at the end of two months. The patients have been in the follow-up program for a mean period of 3 years and they do not have complaints of incontinence.

\section{DISCUSSION}

Mortality and morbidity following perianal area injuries are high. The most significant cause of morbidity is fecal and urinary incontinence seen in the early and late periods. The early period following injury is a process which necessitates important decision making stages like the prevention of infection, need for colostomy, and repair methods. The root cause of the problem in most of the patients with fecal incontinence is sphincter defects that emerge after obstetric trauma or perianal area surgeries. 53\% to $79 \%$ of the patients have injuries at varying degrees following vaginal delivery $(4,5)$. Although the rate of such injuries is too high, not all the injuries cause sphincter damage. The rate of primary obstetric anal sphincter injury is about 18\% in vaginal deliveries (6). Eight studies have been investigated by a meta-analysis and it has been found that $5.7 \%$ of women in their first labor and $6.3 \%$ in their following labors have anal sphincter injuries (7). In another study, a total of 700 patients pregnant with twins have been evaluated and the rate of sphincter injury has been found to be $2.8 \%$ (8). In a study conducted with patients who had vaginal 


\begin{tabular}{|c|c|c|}
\hline & Female & Male \\
\hline Cases & 10 & 5 \\
\hline Age & $24(19-36)$ & $36(25-45)$ \\
\hline Severity of injury & $\begin{array}{l}\text { Type } 4(n=3) \text {, Type } 3 a(n=2), \\
\text { Type } 3 b(n=2) \text {, Type } 3 c(n=3)\end{array}$ & $\begin{array}{l}\text { Full-thickness injury to internal } \\
\text { and external sphincter }(n=5)\end{array}$ \\
\hline Pre-operative time & 10 (1-18) hours ( $n=1,3$ days) & $8(3-15)$ hours \\
\hline Postoperative follow-up time & \multicolumn{2}{|c|}{$3(1-7)$ years } \\
\hline Mean resting pressure & $40(30-60) \mathrm{mmHg}$ & 45 (30-70) mmHg \\
\hline Extrusion pressure & $60(50-100) \mathrm{mmHg}$ & $66(50-120) \mathrm{mmHg}$ \\
\hline Mean duration of extrusion & $26(20-50)$ seconds & $30(20-56)$ seconds \\
\hline Coughing reflex & 68 (54-110) mmHg & $74(54-130) \mathrm{mmHg}$ \\
\hline
\end{tabular}

or c-section deliveries, the authors have found that complaints related to incontinence varied between $13 \%$ and $25 \%$ (9). The rate of fecal incontinence in patients with sphincter injury following delivery is about $7.7 \%$ (10). The rate of incontinence is $6.3 \%$ in nulliparous women, while it is $8.8 \%$ in uniparous women, $8.4 \%$ in secundiparous women, and this rate goes as high as $11.5 \%$ in triparous women and women who had more than 3 deliveries (11). Only $27 \%$ of endoanal ultrasonography results show occult anal sphincter injuries (12). One third of the patients shown to have damage also had symptoms of incontinence. Asymptomatic patients are at risk in the years to come with regards to incontinence. Almost all female patients presented with trauma at delivery. Male patients, on the other hand, had sphincter injury due to falling down from heights.

The creation of episiotomy during delivery prevents uncontrolled perianal fissures. The results of a meta-analysis; however, has revealed that episiotomy increases the risk of fecal incontinence (13). The most significant parameters for sphincter damage in vaginal delivery are interventional delivery and birth-weight of the baby (14). Tertiary level fissures are frequently seen in interventional deliveries with midline episiotomy. Uncontrolled fissures are seen less after medio-lateral episiotomy procedures. Although 6 of our patients had episiotomy, uncontrolled fissures could not be prevented. We believe that the reason for this was the problematic timing of the episiotomy. Although the starting point of the episio-incision was medio-lateral, it continued towards the medial afterwards. Six of these patients had interventional deliveries. Five of the babies had a birth weight of more than 4000 grams.

The first treatment that should be offered for any incontinence patient with anal sphincter defect is primary sphincter repair. Pre-operative intestinal cleaning should be done very carefully. Perioperative antibiotic prophylaxis is necessary. Randomized controlled studies have demonstrated that prophylaxis with sec- ond generation cephalosporin significantly reduces the rate of infection (15). While infection rates following anal sphincter repair done because of vaginal birth injury go as high as 20\%, wound healing problems reach up to $25 \%$ (16). Surgical site infection was not seen in any of our patients. We administer a combination of third generation cephalosporin and metronidazole prophylaxis to our patients and we continue with the treatment for 3 days. We pay specific attention to keep the vagina dry. We believe that the reason why we do not come across such complications as wound site infection and wound split is the careful attention we pay.

The vaginal wall on the front, anal channel mucosa on the back should be repaired in internal and external sphincter procedures. Sphincter repairs can be done as end-to-end or overlapping forms. The difference between suturing the defect end-to-end and overlapping has not been shown in the literature within oneyear of follow-ups (17). We do end-to-end repair in cases with early surgery following injury. We prefer the overlapping method more for chronic cases. We repair all the layers separately with interrupted sutures.

There is no sufficient data on whether a patient who had vaginal injury following vaginal delivery should have her new deliveries by vaginal or c-section delivery. Some studies, however, have reported that the probability of new anal sphincter injury following vaginal delivery is $3 \%$ (18). Nevertheless, we do not recommend our patients to have vaginal delivery. These patients have lower anal manometric pressure than normal patients (although the measurements do not have standard values). Micro or macro sphincter injuries happen in all deliveries. We support the idea that patients should not be exposed to the risk of having possible injuries.

Incontinence can be seen in women with sphincter injuries during delivery after repair. The most significant cause of this is residual anterior sphincter defects (3). Adequate continence might not be achieved in the long term by the primary repair of third 
and fourth degree sphincter fissures that form during delivery. Although primary repair is done during delivery, 15-61\% anal incontinence has been reported. Endoanal ultrasonography results presented in some studies have demonstrated that sphincter injuries up to $91 \%$ remain in patients with fissures repaired by interrupted side-to-side sutures $(3,19)$. Follow-ups up to 3 years have not shown any significant continence problems in our cases. The biofeedback therapy offered to patients experiencing gas incontinence and urogenesis problems has proven to be helpful.

\section{CONCLUSION}

Sphincter repair should be performed at experienced centers controlled by coloproctologists.

Physicians should note that sphincter injuries may happen after every delivery.

Patients should be informed about the fact that they might experience incontinence problems during the follow-ups. We are of the opinion that it is significant to have surgical intervention before tissue edema develops.

Ethics Committee Approval: Ethics committee approval was received for this study from the ethics committee of Necmettin Erbakan University Meram School of Medicine (10.08.2017-2017/361).

Informed Consent: Written informed consent was obtained from patients who participated in this article.

Peer-review: Externally peer-reviewed.

Author Contributions: Concept - M.C.; Design - M.A.Y.; Supervision - M.A.Y.; Resource - M.A.Y.; Materials - M.C.; Data Collection and/or Processing - M.A.Y., Analysis and/or Interpretation - M.A.Y., M.C.; Literature Search - M.A.Y; Writing Manuscript - M.A.Y, M.C.; Critical Reviews - M.A.Y, M.C.

Conflict of Interest: The authors have no conflicts of interest to declare.

Financial Disclosure: The authors declared that this study has received no financial support.

\section{REFERENCES}

1. Landefeld CS, Bowers BJ, Feld AD, Hartmann KE, Hoffman E, Ingber $M J$, et al. National Institutes of Health state-of-the-science conference statement: prevention of fecal and urinary incontinence in adults. Ann Intern Med 2008; 148: 449. [CrossRef]

2. Wald A, Bharucha AE, Cosman BC, Whitehead WE. ACG clinical guideline: management of benign anorectal disorders. Am J Gastroenterol 2014; 109: 1141-57. [CrossRef]

3. Bulut MT. Fekal inkontinans. Menteş B, Bulut MT, Alabaz Ö, Leventoğlu S, editörler. Anorektal bölgenin selim hastalıkları. 1. baskı. Ankara: 2011: 187-216.

4. Smith LA, Price N, SimoniteV, Burns EE. Incidence of and risk factors for perineal trauma: a prospective observational study. BMC Pregnancy Childbirth 2013; 13:59. [CrossRef]
5. Rogers RG, Leeman LM, Borders N, Qualls C, Fullilove AM, Teaf D, et al. Contribution of the second stage of labour to pelvic floor dysfunction: a prospective cohort comparison of nulliparous women. BJOG 2014; 121: 1145-53. [CrossRef]

6. Lowder JL, Burrows LJ, Krohn MA, Weber AM. Risk factors for primary and subsequent anal sphincter lacerations: a comparison of cohorts by parity and prior mode of delivery. Am J Obstet Gynecol 2007; 196: 344.e1-5. [CrossRef]

7. Jha S, Parker V. Risk factors for recurrent obstetric anal sphincter injury (rOASI): a systematic review and meta-analysis. Int Urogynecol J 2016; 27: 849-57. [CrossRef]

8. Rosen H, Barrett J, Okby R, Nevo O, Melamed N. Risk factors for obstetric anal sphincter injuries in twin deliveries: a retrospective review. Int Urogynecol J 2016; 27: 757-62. [CrossRef]

9. Guise JM, Morris C, Osterweil P, Li H, Rosenberg D, Greenlick M. Incidence of fecal incontinence after childbirth. Obstet Gynecol 2007; 109: 281-8. [CrossRef]

10. Melville JL, Fan MY, Newton K, Fenner D. Fecal incontinence in US women: a population-based study. Am J Obstet Gynecol 2005; 193: 2071. [CrossRef]

11. Nygaard I, Barber MD, Burgio KL, Kenton K, Meikle S, Schaffer J, et al; Pelvic Floor Disorders Network. Prevalence of symptomatic pelvic floor disorders in US women. JAMA 2008; 300: 1311. [CrossRef]

12. Oberwalder M, Connor J, Wexner SD. Meta-analysis to determine the incidence of obstetric anal sphincter damage. Br J Surg 2003; 90: 1333-7. [CrossRef]

13. LaCross A, Groff M, Smaldone A. Obstetric anal sphincter injury and anal incontinence following vaginal birth: a systematic review and meta-analysis. J Midwifery Womens Health 2015; 60: 37-47. [CrossRef]

14. Pergialiotis V, Vlachos D, Protopapas A, Pappa K, Vlachos G. Risk factors for severe perineal lacerations during childbirth. Int I Gynaecol Obstet 2014; 125: 6-14. [CrossRef]

15. Duggal N, Mercado C, Daniels K, Bujor A, Caughey AB, El-Sayed YY. Antibiotic prophylaxis for prevention of postpartum perineal wound complications: a randomized controlled trial. Obstet Gynecol 2008; 111: 1268-73. [CrossRef]

16. Lewicky-Gaupp C, Leader-Cramer A, Johnson LL, Kenton K, Gossett $D R$. Wound complication safter obstetric anal sphincter injuries. Obstet Gynecol 2015; 125: 1088-93. [CrossRef]

17. Fernando RJ, Sultan AH, Kettle C, Thakar R. Methods of repair for obstetric anal sphincter injury. Cochrane Database Syst Rev 2013; CD002866. [CrossRef]

18. Peirce C, Murphy C, Fitzpatrick M, Cassidy M, Daly L, O'Connell PR, et al. Randomised controlled trial comparing early home biofeedback physiotherapy with pelvic floor exercises for the treatment of thirddegreetears (EBAPT Trial). BJOG 2013; 120: 1240-7. [CrossRef]

19. Practice Bulletin No. 165: Prevention and Management of Obstetric Lacerations at Vaginal Delivery. American College of Obstetricians and Gynecologists' Committee on Practice Bulletins--Obstetrics. Obstet Gynecol 2016; 128: e1-e15. [CrossRef] 


\section{ORIJINAL ÇALIŞMA-ÖZET}

Turk J Surg 2019; 35 (1): 44-48

\section{Cerrahi dışı akut travmatik perianal yaralanmalar}

Mehmet Aykut Yıldııım ${ }^{1}$, Murat Çakır ${ }^{1}$

${ }^{1}$ Necmettin Erbakan Üniversitesi Meram Tıp Fakültesi, Genel Cerrahi Anabilim Dalı, Konya, Türkiye

\section{ÖZET}

Giriş ve Amaç: Fekal inkotinans tanısı zor ve karmaşıktır. Fekal inkontinansın en önemli nedenlerinden biri perianal bölgede oluşan travmadır. Bu travmanın en önemli nedeni doğum travmasıdır. Hastaları değerlendirmek ve yapılacak tedaviye karar vermek zordur. Sfinkter hasar derecesi ve perianal bölgedeki organlarda oluşan yaralanma cerrahi yöntemi belirler. Perianal bölgede oluşan akut yaralanma nedeniyle sfinkter tamiri yapılan olgularımızı incelemek istedik.

Gereç ve Yöntem: Necmettin Erbakan Üniversitesi Meram Tıp Fakültesi Genel Cerrahi Kliniği 2010-2015 yılları arasında başvuran perianal bölge yaralanması olan 15 hastanın verileri retrospektif olarak incelendi. Hastaların yaş, cinsiyet, yaralanma şekli, yaralanma derecesi, ilk müdahale zamanı, onarım şekli, yara problemleri ve postoperatif komplikasyonları değerlendirildi.

Bulgular: Hastaların beşi erkek ve 10'u kadındı. Kadınların dokuzu doğum travması, biri ise cinsel ilişki esnasında yaralanma gelişmişti. Hastaların tamamına sfinteroplasti yapılırken, 10'una levatoroplasti uygulandı.

Sonuç: Cerrahi müdahalenin doku ödemi gelişmeden yapılmasının önemli olduğu kanaatindeyiz.

Anahtar Kelimeler: Fekal inkontinans, travma, perianal

Doi: $10.5578 /$ turkjsurg.4188 